\title{
Evidence for a Decline in Northern Quebec (Nunavik) Belugas
}

\author{
M.O. HAMMILL,${ }^{1,2}$ V. LESAGE, ${ }^{1}$ J.-F. GOSSELIN,${ }^{1}$ H. BOURDAGES, ${ }^{1}$ B.G.E. de MARCH ${ }^{3}$ and M.C.S. KINGSLEY ${ }^{4}$
}

(Received 6 January 2003; accepted in revised form 15 January 2004)

\begin{abstract}
Systematic aerial line-transect surveys of beluga whales, Delphinapterus leucas, were conducted in James Bay, eastern Hudson Bay, and Ungava Bay from 14 August to 3 September 2001. An estimated 7901 (SE = 1744) and 1155 (SE = 507) belugas were present at the surface in the offshore areas of James Bay and Hudson Bay, respectively. An additional 39 animals were observed in estuaries during the coastal survey, resulting in an index estimate of 1194 ( $\mathrm{SE}=507$ ) in eastern Hudson Bay. No belugas were observed in Ungava Bay. Observations from systematic surveys conducted in 1993 and 2001 were analyzed using both line-transect and strip-transect methods to allow comparisons with the strip-transect survey conducted in 1985. A population model incorporating harvest information and fitted to the aerial survey data indicates that the number of belugas in eastern Hudson Bay has declined by almost half because of high harvest levels. Subsistence harvest levels must be reduced significantly if this population is to recover.
\end{abstract}

Key words: beluga, aerial survey, Nunavik, harvesting, northern Quebec, abundance

RÉSUMÉ. Des relevés aériens systématiques de bélugas (Delphinapterus leucas) par échantillonnage en ligne ont été effectués dans la baie James, l'est de la baie d'Hudson et la baie d'Ungava du 14 août au 3 septembre 2001. On a estimé respectivement à 7901 (erreur-type $=1744$ ) et 1155 (erreur-type $=507)$ le nombre de bélugas présents en surface au large des côtes de la baie James et de la baie d'Hudson. Trente-neuf individus de plus ont été observés dans les estuaires pendant le relevé côtier, produisant ainsi un indice de 1194 (erreur-type = 507) dans l'est de la baie d'Hudson. Aucun béluga n'a été vu dans la baie d'Ungava. Les observations des relevés systématiques de 1993 et de 2001 ont été analysées selon deux méthodes d'échantillonnage, en ligne et en bande, afin de permettre une comparaison avec le relevé en bande de 1985. Un modèle d'analyse des populations, intégrant les données de prélèvements et ajusté aux résultats du relevé aérien, indique que le nombre de bélugas dans la baie d'Hudson a presque diminué de moitié en raison du taux élevé des prélèvements de subsistance. Ces derniers doivent être réduits de façon importante pour que cette population puisse se rétablir.

Mots clés: béluga, relevé aérien, Nunavik, prélèvements, Nord québécois, abondance

\section{INTRODUCTION}

The beluga or white whale (Delphinapterus leucas) is a medium-sized odontocete, widely distributed throughout Arctic waters. Within the James Bay and Hudson Bay areas of the Canadian North, belugas summer along all coasts, and at one time they were common throughout Ungava Bay (Smith and Hammill, 1986; Richard et al., 1990). During winter, Hudson, James, and Ungava Bays are largely ice-covered. Although some belugas may overwinter in small ice-free areas or regions of shifting ice in Hudson Bay and James Bay, most of them migrate from the bay to overwinter in Hudson Strait (Jonkel, 1969; Finley et al., 1982). Animals in Hudson Bay and Ungava Bay were once harvested commercially (Doan and Douglas, 1953; Finley et al., 1982; Reeves and Mitchell, 1987a, b). Depletion of beluga stocks in eastern Hudson Bay and Ungava Bay probably began in the 19th century, with commercial harvesting in northern Quebec (Nunavik) by the Hudson's Bay Company, and high subsistence harvests have likely limited the opportunity for stocks to recover (Finley et al., 1982; Reeves and Mitchell, 1987a, b). Nearshore aerial surveys to assess beluga abundance along the Hudson Bay coast of Quebec in 1978 and 1980 indicated that numbers were as low as $160-250$ animalsmuch lower than the 6000-7000 or more animals thought to have occupied the area during the previous century (Breton-Provencher, 1980; Finley et al., 1982). Coastal surveys flown in Ungava Bay suggested even lower numbers of around 50 animals, concentrated around the Mucalic River (Finley et al., 1982). Concerns over the apparent low numbers of whales in the waters adjoining northern Quebec (Nunavik) led to a series of systematic visual aerial surveys along transects covering nearshore and offshore areas of James Bay, eastern Hudson Bay (EHB), and Ungava Bay during July and August 1985 (Smith and Hammill, 1986). Survey estimates (not corrected for diving animals) were $1200(\mathrm{SE}=290)$ belugas in James Bay,

\footnotetext{
${ }^{1}$ Department of Fisheries and Oceans, Box 1000, Mont-Joli, Quebec G5H 3Z4, Canada

${ }^{2}$ Corresponding author: hammillm@dfo-mpo.gc.ca

${ }^{3}$ Department of Fisheries and Oceans, 501 University Crescent, Winnipeg, Manitoba R3T 2N2, Canada

${ }^{4}$ Greenland Institute of Natural Resources, Box 570, DK-3900 Nuuk, Greenland

(C) The Arctic Institute of North America
} 


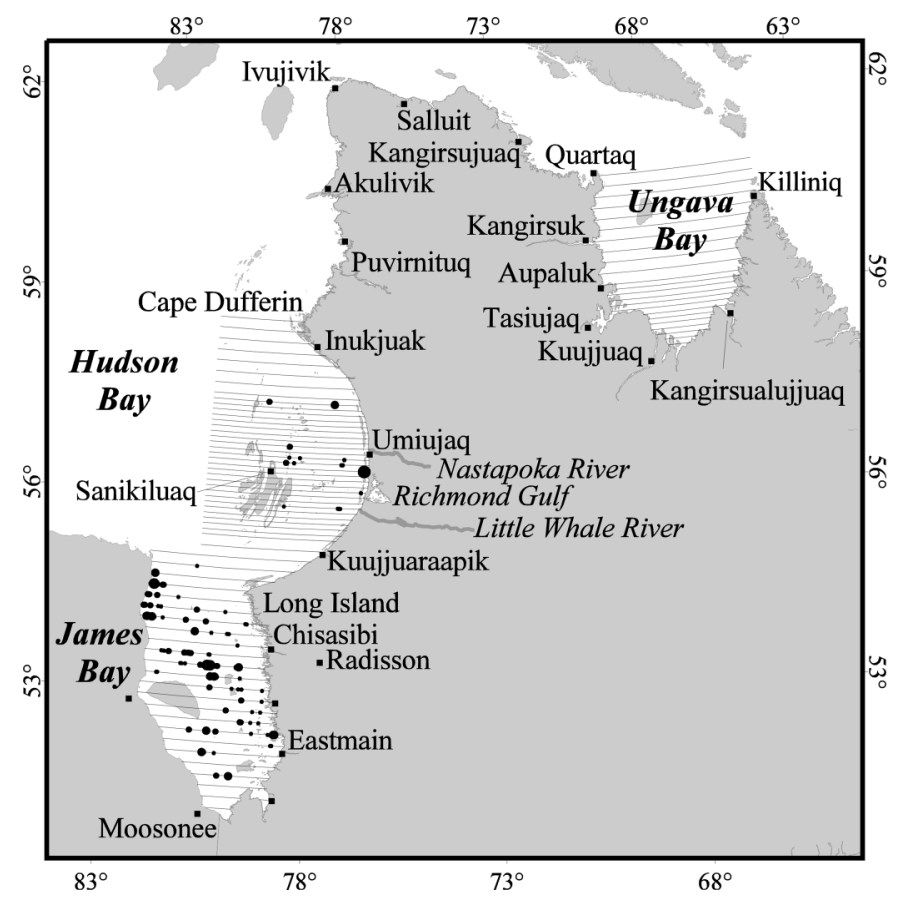

FIG. 1. Beluga sightings during the 2001 systematic transect surveys in James Bay $\left(<55^{\circ} \mathrm{N}\right.$ latitude $)$ in the eastern Hudson Bay $\operatorname{arc}\left(55^{\circ}-59^{\circ} \mathrm{N}\right.$ latitude $)$, and in Ungava Bay.

and $1400(\mathrm{SE}=165)$ in EHB. No whales were seen along the transects in Ungava Bay, while coastal surveys of the area saw fewer than 10 whales on any survey day. Because of these low estimates for EHB and Ungava Bay, limits were placed on harvesting, through a combination of quotas and seasonal and regional closures, to allow the beluga stocks to recover (Reeves and Mitchell, 1989). Concern for belugas in the waters adjoining Nunavik also led the Committee on the Status of Endangered Wildlife in Canada (COSEWIC) to designate belugas in Ungava Bay as 'Endangered,' and EHB belugas as 'Threatened' (Reeves and Mitchell, 1989). Continued subsistence hunting underlined a need to monitor changes in beluga population size. A second series of aerial surveys flown in JulyAugust 1993 detected many more belugas in James Bay than had been seen in 1985 , but confirmed the low numbers in EHB and Ungava Bay (Kingsley, 2000).

Considerably more belugas are seen during summer along the western Hudson Bay (WHB) coast. Estimates of 27000 (not corrected for diving) were obtained from surveys flown along the Ontario, Manitoba, and Northwest Territories coasts of Hudson Bay (Richard et al., 1990).

Initially belugas in Hudson Bay were divided into stocks according to their summer distributions (Reeves and Mitchell, 1987b). Molecular genetic analyses of samples collected by hunters from EHB and WHB support the division between an EHB population centered on the Hudson Bay arc and a WHB population that encompasses one or several stocks from elsewhere in Hudson Bay (Brennin et al., 1997; Brown Gladden et al., 1997, 1999; de March and Maiers, 2001). Unfortunately, few samples have been obtained from belugas in Ungava Bay and
James Bay to clarify the population relationships of these animals to other belugas in Hudson Bay.

The hunting of beluga whales is an important traditional activity for the Inuit, both as a means of obtaining food and defining their culture and as a recreational activity (Kingsley, 2000). At the same time, the Nunavik human population is increasing rapidly (Anonymous, 1999). Fourteen communities in Ungava Bay, Hudson Strait, and eastern Hudson Bay harvest natural resources (Table 1; Fig. 1). The subsistence needs of this increasing population must be balanced with the need to allow a small beluga population to recover.

In this study, we present results from aerial surveys flown in 2001 and compare our estimates to those of surveys flown in 1985 and 1993. We also fit a population model to the aerial survey estimates, incorporating information on numbers of animals harvested and the stock composition of the harvest. The model is intended to monitor changes in the population over time, within the challenging context of managing a small beluga population subjected to a subsistence harvest.

\section{MATERIAL AND METHODS}

The survey was flown along the same transect lines used during the 1985 and 1993 surveys (Smith and Hammill, 1986; Kingsley, 2000). Flights were not initiated if conditions exceeded Beaufort Sea State 4. Observations were recorded on microcassettes by two observers seated in the back of a Cessna 337 equipped with a GPS and bubble windows flying at $457.2 \mathrm{~m}(1500 \mathrm{ft})$ at $240 \mathrm{~km} / \mathrm{h}$ (130 knots). Before conducting the survey in northern Quebec, observers flew several lines over belugas in the St. Lawrence River estuary to practice collecting linetransect data and detecting whales.

For each animal, the angle from the horizontal was measured to the nearest degree using a Suunto inclinometer. The distance of the animal from the aircraft $(\mathrm{m})$ was then estimated by dividing the altitude of the aircraft $(\mathrm{m})$ by the tangent of the measured angle. Most angles were measured when animals were passing abeam of the plane. For some animals that were quite distant, the relative bearing of the animal from the track line was measured on an angle meter fixed to the side of the windows. In these cases, we estimated the distance from the transect line as the product of the sine of the relative bearing angle and the horizontal distance from the plane.

Sea conditions (Beaufort), glare, and cloud cover (in eighths) were recorded at the beginning and end of each transect, two to four times each hour, and whenever noticeable changes occurred.

Coastal surveys were flown using the same aircraft at an altitude of $305 \mathrm{~m}$ (1000 feet), with some lower flying at $152 \mathrm{~m}$ (500 feet) for narrow estuaries or bays. During the coastal survey of EHB on 28 August, a third observer from Inukjuak sat in the co-pilot seat. This survey consisted of 
TABLE 1. Beluga harvest statistics for Nunavik communities from 1985-2001 (updated from Lesage et al., 2001; D. Baillargeon, Fisheries and Oceans Canada, Quebec Region, unpubl. data).

\begin{tabular}{|c|c|c|c|c|c|c|c|c|c|c|c|c|c|c|c|c|c|}
\hline \multirow[b]{2}{*}{ Community } & \multicolumn{17}{|c|}{ Year } \\
\hline & 1985 & 1986 & 1987 & 1988 & 1989 & 1990 & 1991 & 1992 & 1993 & 1994 & 1995 & 1996 & 1997 & 1998 & 1999 & 2000 & 2001 \\
\hline Kuujjuaraapik & 40 & 10 & 11 & 0 & 8 & 8 & 12 & 16 & 12 & 22 & 14 & 15 & 11 & 14 & 14 & 8 & 15 \\
\hline Umiujaq & - & 3 & 15 & 12 & 18 & 12 & 24 & 24 & 19 & 18 & 21 & 19 & 19 & 18 & 24 & 19 & 17 \\
\hline Inukjuak & 11 & 7 & 11 & 17 & 17 & 11 & 20 & 16 & 13 & 19 & 20 & 22 & 21 & 18 & 19 & 35 & 25 \\
\hline Puvirnituq & - & 23 & 16 & 23 & 41 & 22 & 50 & 22 & 23 & 23 & 36 & 38 & 33 & 36 & 27 & 29 & 50 \\
\hline Akulivik & 11 & 12 & 12 & 12 & 19 & 9 & 18 & 16 & 16 & 20 & 18 & 15 & 24 & 17 & 22 & 12 & 33 \\
\hline EHB Total & 62 & 55 & 65 & 64 & 103 & 62 & 124 & 94 & 83 & 102 & 109 & 109 & 108 & 103 & 106 & 103 & 140 \\
\hline Ivujivik & 35 & 5 & 24 & 19 & 118 & 20 & 31 & 2 & 37 & 24 & 38 & 34 & 22 & 44 & 37 & 36 & 13 \\
\hline Salluit & 22 & 24 & 20 & 16 & 53 & 17 & 28 & 19 & 37 & 46 & 40 & 32 & 46 & 54 & 33 & 28 & 57 \\
\hline Kangirsujuaq & 32 & 22 & 28 & 28 & 28 & 24 & 39 & 28 & 29 & 34 & 22 & 25 & 25 & 22 & 27 & 26 & 34 \\
\hline Quartaq & 34 & 21 & 21 & 15 & 35 & 18 & 29 & 22 & 32 & 35 & 28 & 23 & 31 & 32 & 24 & 26 & 60 \\
\hline HS Total & 123 & 72 & 93 & 78 & 234 & 79 & 127 & 71 & 135 & 139 & 128 & 114 & 124 & 152 & 121 & 116 & 164 \\
\hline Kangirsuk & 7 & 9 & 8 & 7 & 11 & 10 & 12 & 3 & 12 & 10 & 10 & 16 & 16 & 13 & 19 & 12 & 24 \\
\hline Aupaluk & 3 & 3 & 1 & 2 & 3 & 5 & 9 & 0 & 3 & 6 & 6 & 8 & 8 & 4 & 13 & 8 & 7 \\
\hline Tasiujaq & 9 & 14 & 4 & 11 & 9 & 3 & 2 & 2 & 7 & 12 & 11 & 6 & 14 & 17 & 21 & 13 & 23 \\
\hline Kuujjuaq & 2 & 10 & 5 & 2 & 8 & 3 & 3 & 4 & 12 & 9 & 10 & 5 & 13 & 10 & 8 & 7 & 20 \\
\hline Kangirsualujjuaq & 3 & 5 & 2 & 1 & 0 & 0 & 7 & 0 & 4 & 11 & 2 & 9 & 7 & 3 & 7 & 11 & 17 \\
\hline Killiniq & 8 & 1 & 0 & 4 & - & - & - & - & - & - & - & - & - & - & - & - & - \\
\hline UB Total & 32 & 42 & 20 & 27 & 31 & 21 & 33 & 9 & 38 & 48 & 39 & 44 & 58 & 47 & 68 & 51 & 91 \\
\hline Nunavik Total & 217 & 169 & 178 & 169 & 368 & 162 & 284 & 174 & 256 & 289 & 276 & 267 & 290 & 302 & 295 & 270 & 395 \\
\hline
\end{tabular}

two legs. The first flight started at Inukjuak and covered the mainland coast and Richmond Gulf south to Long Island at the entrance to James Bay, with a stop at Kuujjuaraapik. The second flight started from Kuujjuaraapik and surveyed the offshore islands starting west of Umiujaq and continuing north of Inukjuak to Cape Dufferin at the top of the Hudson Bay arc (Fig. 1). The Ungava Bay coasts were surveyed by two flights on 4 September. A morning flight covered the east coast from Kuujjuaq to Killiniq, which is located at the northeastern tip of Ungava Bay, including all large estuaries and bays. A second flight covered the coast and all bays from Kuujjuaq to Quartaq. On 5 September, Hudson Strait and the northeast Hudson Bay coasts were surveyed from Quartaq through the Strait and south along the coast to Cape Dufferin, just north of Inukjuak, including the offshore Islands and passages in the Ivujivik area. The distance from the coast on these flights was kept short enough so that the observer on the coast side of the plane was confident that he would not miss belugas between the plane and the coast. Belugas on both sides of the plane were monitored, and observation times and distances were recorded on microcassettes. The total count of belugas within estuaries was added to the estimated number of belugas on the offshore systematic survey to estimate beluga abundance in each stratum. Animals outside of the estuaries were not included in the final estimates, since they were theoretically already included in the systematic survey lines that extended to the coast. The plane circled all groups detected during the coastal survey to provide the best estimate of total numbers.

To allow comparison with results from previous surveys of 1985 and 1993, data were analyzed using the published line-transect (Kingsley, 2000; Gosselin et al., 2002) and strip-transect methods (Smith and Hammill, 1986).

For the line-transect analysis, the decreasing probability of seeing whales with increasing distance from the aircraft was modeled using a modified Richards sigmoidal growth curve (Richards, 1959), with a restrained inflection point below 0.9 of probability of detection (Kingsley, 2000). Since observers could not see directly under the plane, a sine ${ }^{2}$ function was also fitted to the observations between the aircraft and the point of maximum detection $\left(g_{\max }=1\right)$. A single combined sine ${ }^{2}$ and Richards's modified function was fitted to the pooled truncated distribution of perpendicular distances by maximum likelihood. A single effective strip width (ESW) for all of James Bay and eastern Hudson Bay was estimated as the integral of the combined sine ${ }^{2}$ and Richards sighting curve.

The total number of detectable belugas in each stratum $(\hat{N})$ was estimated as the sum of the number of belugas counted in estuaries $\left(N_{e}\right)$ during coastal surveys and the number of belugas detectable at the surface during the systematic offshore survey $\left(\hat{N}_{s}\right)$.

The number estimated at the surface $\left(\hat{N}_{s}\right)$ is the product of the number of belugas counted on the transects weighted by the proportion of the area of the stratum covered:

$$
\hat{N}_{s}=\tilde{k} T_{s} B_{s}
$$

where $T_{s}$ is the transect spacing in $\mathrm{km}, B_{s}$ is the total count of belugas for each stratum, and $\tilde{k}$ is the bias-reduced expansion factor, $\hat{k}$, which is the reciprocal of the twosided ESW (Kingsley, 2000).

The variance estimate for this line-transect survey is the sum of the sampling variance $\left(V_{s}\right)$ and the variance 
associated with estimating the expansion factor $\left(V_{k}\right)$. The latter comes from the uncertainty related to modeling the detection of each individual whale's perpendicular distance. For systematic samples, the sampling variance is estimated from the serial differences in counts between consecutive lines (Cochran, 1977; Kingsley, 2000). The variance from the estimation of the expansion factor may be affected by the within-line dependency of the observations and was therefore estimated with a jackknife procedure, using clusters as resampling units (Efron, 1982; Kingsley, 2000).

In review, it was suggested that we repeat the analysis using the DISTANCE software because it is recognized as a more standard line-transect analysis method (Buckland et al., 1993). A detection model was estimated for each of the 1993 and 2001 surveys using all distances within each year. Model selection (between uniform, half-normal, hazard-rate, and negative exponential) was done using Akaike's Information Criteria (AIC) for models that provided reasonable fits close to the track line. Expected cluster size was estimated by the regression of the ln of cluster size $\left(\ln \left(\mathrm{s}_{\mathrm{i}}\right)\right)$ on the detection function $\left(\mathrm{g}\left(\mathrm{x}_{\mathrm{i}}\right)\right)(p<0.15)$, or by mean cluster size when the regression was not significant. After estimating encounter rate and expected cluster size for each stratum, we estimated variances around these values by bootstrapping, using lines as resampling units $(n=999)$.

Observations of whales with a perpendicular distance of up to $1000 \mathrm{~m}$ were used to mimic counts that would have been obtained if a strip-transect survey design had been used in 1993 and 2001. To estimate the weighted number of belugas in each stratum and its associated variance, we used equations similar to those used for the line-transect survey mentioned above, where the bias-reduced expansion factor $\tilde{k}$ is replaced by $k$, the reciprocal of the two-sided strip width (Kingsley et al., 1985; Smith and Hammill, 1986).

Changes in population size over time were examined using a discrete time parameterization of the Pella and Thomlinson model (1969; Innes and Stewart, 2002), where the estimated population size $\left(N_{t+1}\right)$ at time $t+1$ is described by:

$$
N_{t+1}=N_{t}+N_{t}\left(\lambda_{\max }-1\right)\left(1-\left(N_{t} / N_{1854}\right)^{\theta}\right)-b H_{t}
$$

$N_{t}$ is the population size at time $t ; N_{1854}$ is estimated pristine population size in 1854; and $\theta$ is a shaping parameter of the density-dependent response. $\lambda_{\max }$ is the maximum rate of increase, $H_{t}$ is the reported harvest by the 14 villages in Nunavik, which includes eastern Hudson Bay, Hudson Strait, and Ungava Bay (Fig. 1), and $b$ is a parameter to account for animals that are killed, but not reported (struckand-lost). This term includes animals that may have been wounded, but died elsewhere; animals that were killed, but not recovered; and animals that were killed and recovered, but not reported.

Index estimates for the population are available from aerial surveys flown in 1985, 1993, and 2001. Correction factors were required to adjust the aerial survey numbers to account for animals not visible (diving) when the survey plane passed overhead. We used an estimated proportion $\left(P_{0}\right)$ of animals visible from an aerial survey platform of 0.478 (SE $=0.0625)$, which was developed from vertical overflight experiments in the St. Lawrence River estuary (Kingsley and Gauthier, 2002). This area has visibility conditions similar to those we often observe in Hudson Bay. This parameter was assumed to follow a normal distribution. It was used here to obtain an estimate of population size $(N)$ by correcting abundance estimates obtained from the line-transect surveys $\left(N_{\text {survey }}\right)$. Belugas detected in estuaries $\left(N_{\text {estuary }}\right)$ were assumed to represent total counts:

$$
N_{t}=N_{\text {survey }} / P_{0}+N_{\text {estuary }}
$$

Belugas are characterized by early reproduction (age 4-7 years), low reproductive rates (crude birth rate: $0.26-$ 0.47 ), and a long lifespan (longevity $=35$ years) (Sergeant, 1973; Burns and Seaman, 1985; Doidge, 1990; Kingsley et al., 1995). Little information is available on the maximum natural rate of increase $\left(\lambda_{\max }\right)$, but rates of increase of 1.026 to 1.037 have been suggested (Kingsley et al., 1995; Doidge, 1990; Innes and Stewart, 2002). These rates are similar to rates of 1.02 to 1.04 for species with similar life histories, such as narwhal (Monodon monoceros), pilot whale (Globicephala melaena), and spotted dolphin (Stenella plagiodon) (Kasuya et al., 1988; Kingsley, 1989; Barlow and Boveng, 1991). Therefore, $\lambda_{\max }$ in the model was described by a uniform distribution that varied between 1.02 and 1.04 .

Commercial harvesting of EHB belugas conducted by the Hudson's Bay Company began as early as the 1750s, but most effort was expended between the 1850s and 1860s (Reeves and Mitchell, 1987b). A crude minimum estimate of the 1854 population size by Reeves and Mitchell (1987b) is 6600 animals. Using a less conservative approach, Reeves and Mitchell (1987b) suggested that the 1854 population size could have been higher at around 7875 animals. These estimates may still be conservative owing to the incompleteness of the records (Reeves and Mitchell, 1987b) and the fact that subsistence harvests of EHB animals by Inuit living along the EHB coast and in Hudson Strait were not incorporated into the calculations. $N_{1854}$ was set at 7875 in the model.

Theta $(\theta)$ is a shaping parameter that describes where the maximum net productivity level occurs. This parameter was described by a uniform distribution lying between 1.17 and 7.14 (Innes and Stewart, 2002).

Catch statistics are available from each of the communities (Table 1) (Lesage et al., 2001). Genetic data indicate that the communities of Kuujjuaraapik, Umiujaq, and Inukjuak harvest only belugas belonging to the EHB population. Communities hunting in Hudson Strait and Ungava Bay harvest animals from both the WHB and the EHB beluga populations. Among communities from EHB and Hudson Strait that harvest in Hudson Strait, the proportion 
of EHB animals in the catch was 0.22 ( $\mathrm{SE}=0.036$, $n=131$ ), while for communities harvesting in Ungava Bay, the proportion was $0.31(\mathrm{SE}=0.082, n=32)$ (de March and Maiers, 2001). Some communities have changed their hunting patterns over time. Before 1995, Puvirnituq hunters stayed largely at the Nastapoka River, but since then they have shifted their hunting effort towards Hudson Strait. Therefore, until 1995, 100\% of the harvest by Puvirnituq was attributed to EHB belugas. Between 1995 and 2001, 22\% of the harvest consisted of EHB belugas. Very little information is available concerning the composition of the Akulivik harvest. We assumed that their harvest comprised EHB belugas (22\%) and WHB belugas (78\%) during the entire period (de March and Maiers, 2001; de March and Postma, 2003). The proportion of EHB animals in the harvest was described by a binomial distribution (Bin $\left(p, n_{t}\right)$ ), where $\mathrm{p}$ is the estimated mean proportion and $\mathrm{n}$ is the number of animals harvested from that area in year $(t)$.

Harvest statistics are based on verbal reports to a community agent during the hunting season. Hunters are supposed to report the numbers of animals that are struck and lost, but the bias accuracy of these reports is not known. A parameter for non-reporting $(b)$ was included in the model, but was constrained to lie between 1 and 4 (Innes and Stewart, 2002).

Changes in the estimated size of the EHB beluga population were determined by fitting the model to the 1985 , 1993, and 2001 aerial survey estimates (corrected for diving animals). To minimize the difference between the model estimates and the aerial survey estimates, we adjusted the 1985 population size, which represents the start of the modeling period, and $b$, the struck-and-lost parameter (Risk Optimizer, Palisade Corporation, Newfield, New York). The algorithm operated as follows: 1) select values for the 1985 population size and for struck-and-lost $(b)$; 2) sample from the assigned distributions for each input variable; 3) calculate the population trajectories and the sum of squares for the trajectory; 4 ) repeat steps 2 and 3 (1000 times); 5) calculate the mean of the sum of squares (MSS) for the 1000 iterations; 6) repeat steps 4 and 5 (5000 times). After 5000 simulations, we retained the values for the 1985 population size and $b$ in the model that generated the smallest MSS. The expected impacts of continued hunting at current levels, estimates of acceptable harvest levels that would result in no change in the population size (replacement yields), and harvest levels that would allow the population to increase at a rate of $1 \%$ were examined by re-running the model $(n=5000)$. We kept the 1985 population size fixed (as estimated above by the model), but allowed the struck-and-lost term to vary by assuming a normal distribution with a mean equal to the fitted value and a coefficient of variation for this term of $30 \%$. Other parameters in the model were allowed to vary according to the statistical distributions defined above. For each run of the model, we drew values from the sample distributions (Latin Hypercube) and calculated a population trajectory
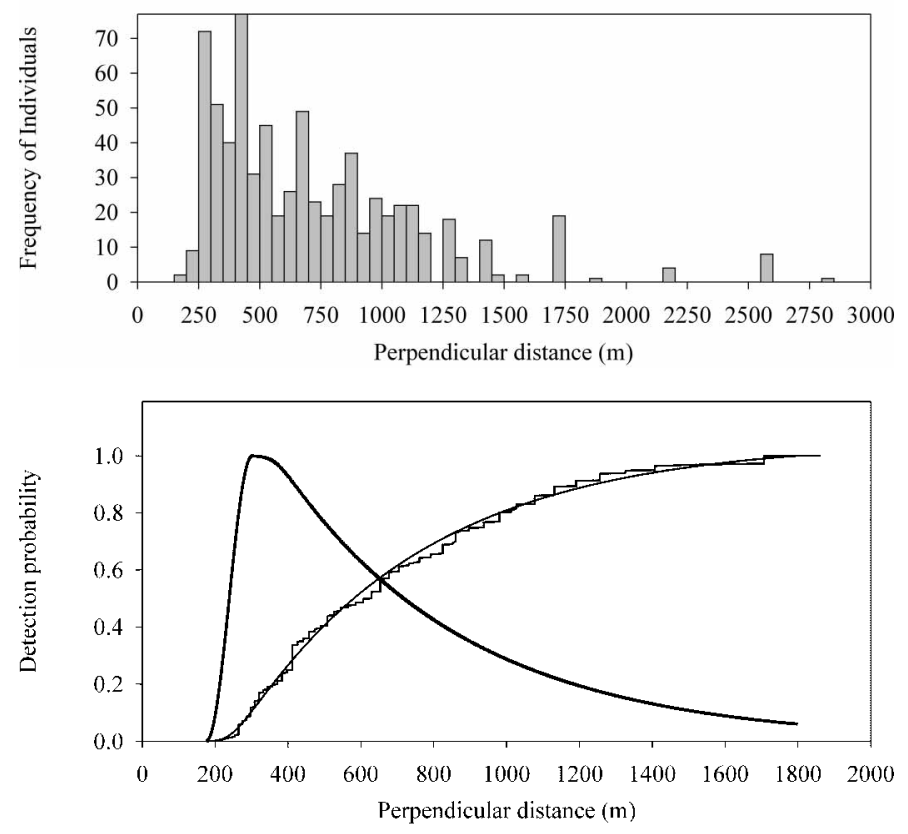

FIG. 2. (a) Frequency of detected perpendicular distances from the track line of individual belugas detected during a systematic aerial survey of James Bay and eastern Hudson Bay from 14 to 27 August 2001. Observations are grouped in $50 \mathrm{~m}$ bins on the graph, but the combined sine ${ }^{2}$-Richards curve was fitted to the ungrouped data. (b) Detection probability function fitted to the ungrouped perpendicular observations of individual belugas during the systematic linetransect survey of James Bay and eastern Hudson Bay in August 2001.

using @RISK software (Palisade Corporation, Newfield, New York).

\section{RESULTS}

The 2001 survey was flown from 14 to 17 August in James Bay. The survey aircraft then moved to Hudson Bay on 18 August to begin flying the east-west lines, starting from the southern portion of the study area and moving northwards. Lines between $56^{\circ} 00^{\prime} \mathrm{N}$ and $56^{\circ} 25^{\prime} \mathrm{N}$ were truncated near the Belcher Islands because of fog and low cloud. This region was surveyed on the afternoon of 27 August. Ungava Bay was surveyed from north to south. Transect lines from $61^{\circ} 00^{\prime}$ to $59^{\circ} 20^{\prime}$ were flown on the 29 and 30 of August. Unfortunately, fog and low clouds delayed the remaining part of the survey until 3 September, when the remaining lines were completed. Transect lines were covered in 73.86 hours of flying, of which 48.19 hours $(65.2 \%)$ were flown in Beaufort Sea State conditions of 2 or less. The mean Beaufort value weighted by time was 1.7 for the whole survey. Mean Beaufort values for the regions were 1.3 for James Bay, 2.9 for the northern part of the eastern Hudson Bay arc, 1.8 for the southern part of EHB, 1.8 for the northern part of Ungava Bay, and 0.7 for the southern part of Ungava Bay.

Few observations of whales were made at distances greater than $1706 \mathrm{~m}$ from the track line (Fig. 2a). From the total 717 observations, we eliminated those of whales more than $1800 \mathrm{~m}$ away from the track line, leaving only 
TABLE 2. Line-transect estimate of surface-detectable belugas in James Bay and eastern Hudson Bay, using the combined sine ${ }^{2}$-Richards modified curve to model decrease in detection function. The systematic aerial survey was conducted from 14 to 27 August 2001.

\begin{tabular}{lccccrr}
\hline \hline & $\begin{array}{c}\text { Number of } \\
\text { belugas used } \\
B_{s}\end{array}$ & $\begin{array}{c}\text { Number of } \\
\text { transects } \\
J_{s}\end{array}$ & $\begin{array}{c}\text { Transect } \\
\text { spacing }(\mathrm{km})\end{array}$ & $\begin{array}{c}\text { Number } \\
\text { in stratum } \\
\hat{N}_{s}\end{array}$ & $\begin{array}{c}\text { Variance } \\
\text { (sampling) } \\
V_{s}\end{array}$ & $\begin{array}{c}\text { Variance } \\
\text { (estimation of } k \text { ) } \\
V_{k}\end{array}$ \\
\hline James Bay & 544 & 25.5 & 18.52 & 7901 & 1513021 & 1528102 \\
E. Hudson Bay south & 159 & 26 & 9.26 & 1155 & 223977 & 32635 \\
E. Hudson Bay north & 0 & 7.5 & 18.52 & 0 & 22.1 \\
Ungava Bay south & 0 & 13 & 9.26 & 0 & 43.8 \\
Ungava Bay north & 0 & 10 & 18.52 & 0 & & \\
\hline \hline
\end{tabular}

${ }^{1}$ Number of belugas used in the analysis after truncation of data.
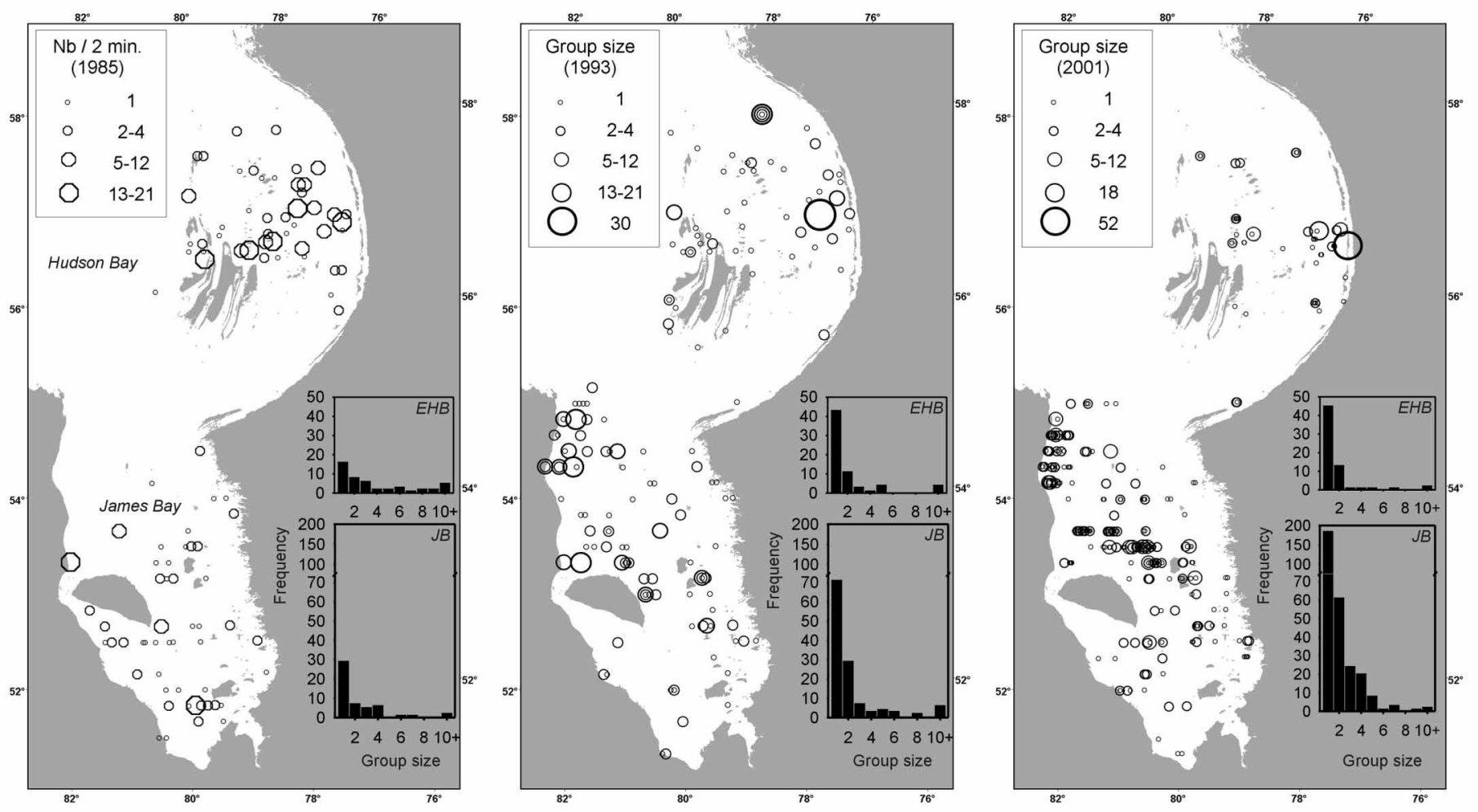

FIG. 3. Differences in geographic distribution of groups detected during the systematic aerial surveys of 1985, 1993, and 2001. Group size was estimated in 1993 and 2001; for 1985, symbol size represents the number of animals detected in two minutes of flying.

696 effective sightings in the sample to model the detection function (Fig. 2b). Maximum detection was reached at $294 \mathrm{~m}$ from the aircraft and then decreased after $346 \mathrm{~m}$. Integration of the detectability function from 0 to $1800 \mathrm{~m}$ provided an effective strip width of $604 \mathrm{~m}$, leading to an expansion factor, $\hat{k}$, of $0.828 / \mathrm{km}$. Since the likelihood function used to fit the model to the recorded observations may be biased for small sample sizes, a standard bias reduction was applied to the estimated expansion factor (Efron, 1982; Kingsley, 2000), resulting in a bias-reduced expansion factor, $\tilde{k}$, of $0.784 / \mathrm{km}(\mathrm{SE}=0.123 / \mathrm{km})$ and a corresponding ESW of $638 \mathrm{~m}$.

In James Bay, 557 belugas were detected in 304 groups, for a mean group size of $1.8(\mathrm{SD}=1.5$, maximum $=12)$. Most animals were seen in the central and northwestern portions of the bay (Figs. 1, 3). The estimated number of belugas at the surface in this area was $7901(\mathrm{SE}=1744)$ animals (Table 2$)$.
In EHB, 160 belugas were detected in 64 different groups. The average group size was $2.5(\mathrm{SD}=6.6)$, but one particularly large group of 52 individuals was detected on line $56^{\circ} 35^{\prime} \mathrm{N}$, in 3-5 m of water off the Nastapoka Islands (Fig. 3). Belugas were seen in larger groups in EHB than in James Bay (Contraharmonic mean or CHM $=20$ for $\mathrm{EHB}$, vs. CHM = 3 for James Bay). Most belugas in EHB (78\%, $N=125)$ were observed on the eastern sections of the southern lines, from $55^{\circ} 30^{\prime} \mathrm{N}$ to $56^{\circ} 45^{\prime} \mathrm{N}$ (Fig. 1). The estimated number of belugas at the surface in EHB was 1155 belugas $(\mathrm{SE}=506)$ (Table 2$)$. No belugas were detected in Ungava Bay.

A total of 69 whales were seen on the EHB coastal flight, at or near the mouth of Little Whale River $(N=39$ and 11) (56 $\left.06^{\prime} 36^{\prime \prime} \mathrm{N}, 76^{\circ} 47^{\prime} 24^{\prime \prime} \mathrm{W}\right)$ and opposite the Nastapoka River $(N=16)$. During the coastal survey of Hudson Strait and the northeastern Hudson Bay coast, 
TABLE 3. Analysis of line transects flown in 1993 (Kingsley, 2000) and 2001 using the software DISTANCE with both left (300 m in 1993 ; $250 \mathrm{~m}$ in 2001) and right truncation (1800 $\mathrm{m}$ in 1993 and 2001). Bootstrap coefficients of variation from line resampling $(n=999)$ are shown in parentheses.

\begin{tabular}{|c|c|c|c|c|c|}
\hline Stratum & Effort $(\mathrm{km})$ & Sightings & Sighting rate & Estimated pod size & Abundance \\
\hline \multicolumn{6}{|l|}{ 1993: } \\
\hline James Bay & 4754 & 119 & $0.0250(15.2)$ & $2.437(21.4)$ & $3882(28.3)$ \\
\hline Eastern Hudson Bay south & 6981 & 55 & $0.0079(15.9)$ & $2.036(25.9)$ & $793(29.9)$ \\
\hline Eastern Hudson Bay north & 1289 & 8 & $0.0062(64.4)$ & $4.750(37.6)$ & $488(47.1)$ \\
\hline Ungava Bay south & 3156 & 0 & & & \\
\hline Ungava Bay north & 2498 & 0 & & & \\
\hline \multicolumn{6}{|l|}{ 2001: } \\
\hline James Bay & 4742 & 294 & $0.0620(20.9)$ & $1.617(8.5)$ & $7899(21.8)$ \\
\hline Eastern Hudson Bay south & 6981 & 63 & $0.0090(30.9)$ & $2.524(34.4)$ & $1394(42.8)$ \\
\hline Eastern Hudson Bay north & 1289 & 0 & 0 & 0 & 0 \\
\hline Ungava Bay south & 1758 & 0 & 0 & 0 & 0 \\
\hline Ungava Bay north & 2498 & 0 & 0 & 0 & 0 \\
\hline
\end{tabular}

TABLE 4. Indices of beluga populations in James Bay, eastern Hudson Bay, and Ungava Bay estimated from three systematic aerial surveys. The 1985 survey data were collected using only strip-transect techniques (Smith and Hammill, 1986). The 1993 and 2001 surveys flew along the same lines as the 1985 surveys, but collected data using line-transect techniques (Kingsley, 2000; this study). These data were analyzed assuming a strip width of $1000 \mathrm{~m}$ on each side of the aircraft. We then adjusted the 1985 survey estimates by first multiplying the striptransect estimates by a line transect-strip transect ratio (Mean $=1.87, \mathrm{SD}=0.268$ ) calculated using the DISTANCE analysis of 1993 and 2001 data and then adding in estuary counts (474 for 1985, 18 for 1993, and 39 for 2001).

\begin{tabular}{|c|c|c|c|c|c|}
\hline \multirow[b]{2}{*}{ Stratum } & \multirow[b]{2}{*}{ Year } & \multirow{2}{*}{$\begin{array}{c}\text { Systematic offshore estimate } \\
\text { Strip-transect } \\
\hat{N}_{s}(\mathrm{SE}) \\
\end{array}$} & \multicolumn{3}{|c|}{ Abundance estimate } \\
\hline & & & $\begin{array}{l}\text { Strip-transect } \\
\hat{N}_{s}(\mathrm{SE}) \\
\end{array}$ & $\begin{array}{l}\text { Richards line-transect } \\
\hat{N}(\mathrm{SE})\end{array}$ & $\begin{array}{c}\text { Distance line-transect } \\
\hat{N}(\mathrm{SE}) \\
\end{array}$ \\
\hline James Bay & $\begin{array}{l}1985 \\
1993 \\
2001\end{array}$ & $\begin{array}{l}1213(290) \\
2296(566) \\
4732(712)\end{array}$ & $\begin{array}{l}1213(290) \\
2296(566) \\
4732(712)\end{array}$ & $\begin{array}{c}1842 \\
3141(787) \\
7901(1744)\end{array}$ & $\begin{array}{c}2256 \\
3882(1099) \\
7899(1722)\end{array}$ \\
\hline EHB & $\begin{array}{l}1985 \\
1993 \\
2001\end{array}$ & $\begin{array}{l}968(165) \\
688(205) \\
620(263)\end{array}$ & $\begin{array}{l}1442(165) \\
706(205) \\
659(263)\end{array}$ & $\begin{array}{c}2089 \\
1032(421) \\
1194(507)\end{array}$ & $\begin{array}{c}2294 \\
1299(330) \\
1433(596)\end{array}$ \\
\hline Ungava Bay & $\begin{array}{l}1985 \\
1993 \\
2001\end{array}$ & $\begin{array}{l}0 \\
0 \\
0\end{array}$ & 0 & $\begin{array}{c}0 \\
88 \\
0\end{array}$ & $\begin{array}{l}0 \\
0 \\
0\end{array}$ \\
\hline
\end{tabular}

three belugas were seen near Salluit. No belugas were seen during the coastal survey in Ungava Bay.

The 1993 and 2001 survey data were also analyzed using DISTANCE. In 1993, there were few sightings within $300 \mathrm{~m}$ from the aircraft. In 2001, few observations of whales were made at distances of less than $250 \mathrm{~m}$ from the aircraft. These values were used as the left-truncation point for each year. Similarly, there were few observations of whales beyond $1800 \mathrm{~m}$ from the aircraft in both years, and the data were right-truncated at this point. In 1993, a Fourier series model (uniform key and one cosine term) provided the best fit to the truncated data set and resulted in an effective strip width (ESW) of $686 \mathrm{~m}$ (Coefficient of variation $[\mathrm{CV}]=4.8 \%$ ). In 2001, a half-normal model provided the best fit to the truncated data set and resulted in an ESW of $554 \mathrm{~m},(\mathrm{CV}=5.5 \%)$. The ESWs produced by DISTANCE are slightly smaller that the ESWs estimated by the $\operatorname{sine}^{2}$ and Richards combined model (ESW $=870 \mathrm{~m}$ in 1993, Kingsley, 2000; $638 \mathrm{~m}$ in 2001) and resulted in slightly higher estimates of abundance (Tables 2, 3, and 4).
The 1993 and 2001 data from James Bay and Hudson Bay were re-analyzed using a strip-transect approach, including in the analyses all observations recorded within a $1000 \mathrm{~m}$ distance on either side of the aircraft, as would be done during a normal strip-transect survey. A comparison of the two approaches indicates that the line-transect population estimates calculated using the Richards curve were $1.59(\mathrm{SD}=0.219, n=4)$ times as high as estimates obtained using strip-transect methods, while the estimated whale numbers obtained using DISTANCE were 1.87 ( $\mathrm{SD}=0.268, n=4)$ times as high as what would have been obtained using strip-transect methods.

We adjusted the aerial survey estimates to correct for animals that were diving when the survey aircraft passed overhead, and then added in the estuarine counts. For the Richards curve analysis, this adjustment resulted in population estimates of 3850, 6565, and 16513 for 1985, 1993, and 2001 respectively in James Bay and 3849, 2137, and 2453 belugas for 1985, 1993, and 2001 respectively in EHB. Using the DISTANCE analysis, these estimates for 
TABLE 5. Estimated population sizes (and SE) for eastern Hudson Bay belugas under different harvest regimes.

\begin{tabular}{|c|c|c|c|c|c|c|c|c|c|}
\hline & \multicolumn{3}{|c|}{$\begin{array}{c}\text { Current harvests } \\
\left(\text { Mean } \mathrm{H}_{\text {reported }}=119\right)\end{array}$} & \multicolumn{3}{|c|}{$\begin{array}{c}\text { Replacement yield } \\
\left(\mathrm{H}_{\text {reported }}=44\right)\end{array}$} & \multicolumn{3}{|c|}{$\begin{array}{c}1 \% \text { rate of increase per year } \\
\left(\mathrm{H}_{\text {reported }}=28\right)\end{array}$} \\
\hline & L95\% & Median & U95\% & L95\% & Median & U95\% & L95\% & Median & U95\% \\
\hline 1985 & 3200 & 3744 & 4300 & 3200 & 3744 & 4300 & 3200 & 3744 & 4300 \\
\hline 2001 & 1550 & 2558 & 3700 & 1550 & 2558 & 3700 & 1550 & 2558 & 3700 \\
\hline 2002 & 1350 & 2380 & 3650 & 1350 & 2380 & 3650 & 1000 & 2217 & 3600 \\
\hline 2006 & 700 & 1910 & 3400 & 1200 & 2380 & 3900 & 1300 & 2490 & 4000 \\
\hline 2015 & 0 & 630 & 2800 & 1200 & 2380 & 3900 & 1100 & 2760 & 5000 \\
\hline
\end{tabular}
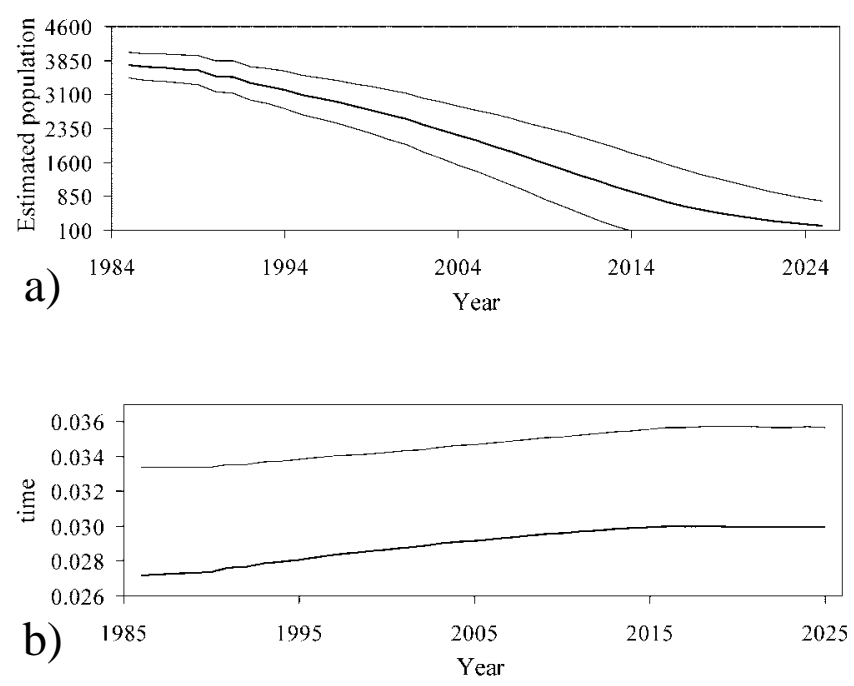

FIG. 4. (a) Predicted trajectory (mean \pm SE) of EHB beluga population from 1985 to 2025 if average reported harvest of the last five years ( $N=119$ belugas) continues. (b) Change in actual rate of increase (mean + SE) in the model over time as the population in (a) declines.

the three surveys are 4740,8113, and 16509 belugas in James Bay and 4257, 2695, and 2952 animals in EHB.

The population model was fitted to the EHB aerial survey estimates from the DISTANCE analyses. The model estimated a struck-and-lost value $(b)$ of 1.56 , and had an initial population size of $3743(\mathrm{SE}=286)$ (Fig. 4a). The model indicated that the population has declined to a mean estimate of $2559(\mathrm{SE}=572)$ in 2001. The maximum natural rate of increase $\left(\lambda_{\max }\right)$ was described by a uniform distribution with limits of 1.02 to 1.04 . The potential rate of increase $(r)$ in the population was limited by theta $(\theta)$, the density-dependent shaping parameter, and by the size of the population with respect to $N_{1854}$. In 1985 , the mean rate of increase was 1.027. As the population declined, $r$ increased, reaching a mean plateau value of 1.03 by 2016 (Fig. 4b). If current harvest levels continue, then there is only a $50 \%$ chance that the population will be greater than zero by 2019 . However, there is considerable uncertainty associated with model outputs, as shown by the large standard errors associated with the predicted trajectory (Fig. 4a). Replacement yield, defined as the reported number of animals that can be harvested over a short period (e.g., 5 years) without resulting in a net decline in estimated median population size, would be 44 (Table 5). Estimated reported harvest levels that would still allow the
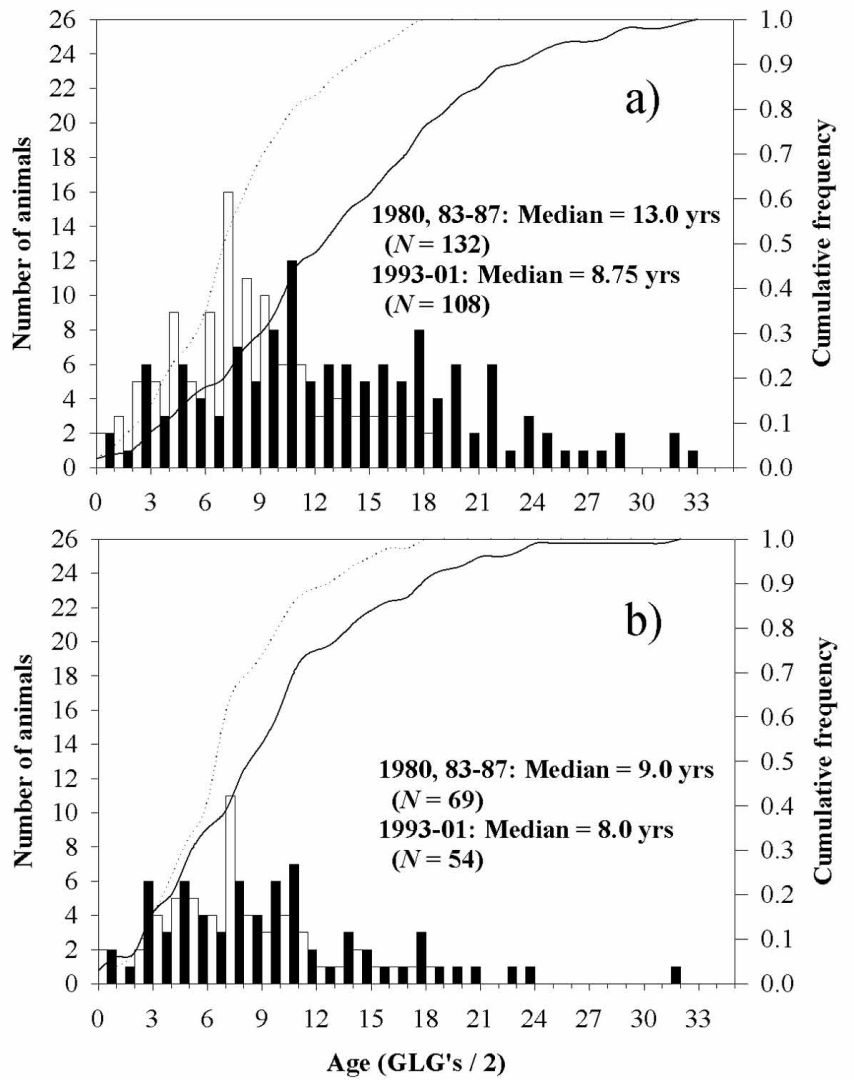

FIG. 5. Age of belugas harvested in Eastern Hudson Bay during 1980, 19831987 (black bars and plain curve; Doidge, 1990) and 1993-2001 (clear bars and dotted curve), presented as age frequencies (bars) and cumulative frequencies (curves), and using worn and unworn teeth (a) or unworn teeth only (b).

population to grow at a rate of $1 \%$ would be 28 belugas. Model outputs were most sensitive to changes in three parameters: the struck-and-lost factor (rank correlation $=$ -0.82 ), the correction factor applied to the aerial survey estimates to account for diving animals (rank correlation $=$ 0.35 ), and the rate of population increase (rank correlation $=0.32$ ). By comparison, changes in population estimates were weakly correlated to theta, the density-dependent shaping parameter (rank correlation $=0.13$ ).

\section{DISCUSSION}

Owing to the combination of inclement weather and the need to cover a large area, surveys of this stock are usually 
completed over a period of several days. Although our survey coverage was extensive, whales may have been either missed or double-counted because they had moved between survey days. However, we do not feel that this is a serious concern. Satellite telemetry information obtained during July and August from whales in this area indicates considerable inshore-offshore movement, but has not shown any maintained large-scale, north to southdirected movements (Kingsley et al., 2001; M.O. Hammill, D.W. Doidge, and V. Lesage, unpubl. data), which would have induced significant bias in our surveys.

Aerial surveys underestimate whale abundance because observers fail to detect whales at the surface (detectability bias) or because animals are diving when the aircraft passes overhead (availability bias). Whale detection is affected by observer performance, by survey conditions such as sea state, or by a failure to satisfy model assumptions (Harwood et al., 1996; Hobbs et al., 2000; DeMaster et al., 2001). DeMaster et al. (2001), flying at a lower altitude (303 m versus $457.2 \mathrm{~m}$ this study) and at $220 \mathrm{~km} / \mathrm{h}$ in a different aircraft type, showed that the density of sightings can be reduced by a third when Beaufort Sea State increases from 1 to 2,3 , or 4 . Given the large areas to be covered in the current survey, it would have been difficult to obtain Beaufort conditions of 1 throughout the entire survey period. Also, the low number of sightings under different conditions limited our ability to correct individual observations or to obtain separate whale sighting probability distributions for different sea states. In some studies, multiple observers have been used to develop detection correction factors (Harwood et al., 1996), but this requires aircraft larger than the Cessna 337 that we used. Consequently, as in the 1985 and 1993 surveys, no adjustment was made for detectability bias.

The three Nunavik beluga abundance surveys completed over the last 15 years all flew the same survey lines, but the 1985 survey data were collected and analyzed using strip-transect methods, while the 1993 and 2001 surveys used a line-transect design (Smith and Hammill, 1986; Kingsley, 2000). Strip-transect surveys assume that all animals located at the surface and between the aircraft and the outer limit of the transect will be detected. However, line-transect methods show that this assumption is not satisfied in beluga aerial surveys. This is because the sightability of animals is poor from the aircraft out to a distance of around $200 \mathrm{~m}$ and then drops off again at a distance of approximately $600 \mathrm{~m}$, depending on window type, aircraft speed, altitude, and observer experience (Harwood et al., 1996; Heide-Jørgenson and Reeves, 1996; Kingsley and Reeves, 1998; Kingsley, 2000). As a result, the 1985 strip-transect survey likely underestimated beluga abundance compared with the 1993 and 2001 surveys. Consequently, we increased the 1985 survey estimates by $\sim 87 \%$ to account for the failure of the $100 \%$ sightability assumption. The 1993 line-transect survey data were analyzed by fitting a combined sine ${ }^{2}$ and Richards modified function to the truncated distribution of perpendicular distances (Kingsley, 2000). In order to ensure comparability between surveys, we repeated this analysis with the 2001 survey data and developed a calibration factor to allow comparison of the 1985 strip-transect results with the later line-transect surveys. We repeated the line-transect analysis with the commonly used software package DISTANCE (Buckland et al., 1993). The DISTANCE estimates were slightly higher $($ Mean $=18 \%, \mathrm{SD}=12 \%$, $n=4)$ than the Richards curve analysis and offered little reduction overall in the coefficient of variation. The DISTANCE software also fit different sighting curves to the 1993 and 2001 surveys. The effect of using different sighting curves on comparisons between surveys is not known. Nonetheless, the exercise illustrates that it is important to use similar approaches when comparing survey results.

In this study, the survey estimates were multiplied by 2.09 (reciprocal of 0.478 ) to account for availability bias (Kingsley and Gauthier, 2002). This correction factor is within the $180 \%-290 \%$ range suggested by satellite telemetry studies that have provided dive information (see Kingsley and Gauthier, 2002) and is the same as a correction factor of $209 \%$ that can be derived from satellite transmitters deployed on belugas in eastern Hudson Bay at the same time that our surveys were flown (Kingsley et al., 2001: Table 2). It provides a minimum correction to aerial survey estimates because satellite transmitters have not been deployed on small belugas, which are less visible than adult animals (Kingsley and Gauthier, 2002).

Beluga abundance in James Bay has increased considerably since 1985, while beluga numbers in EHB have declined. The marked change observed exceeds the $2 \%-$ $4 \%$ considered as likely rates of population increase and the possible maximum of $5 \%$ obtained by using favourable estimates of mortality for species with similar life histories (Reilly and Barlow, 1986). The 1985 survey was flown at the beginning of August, when there was considerable ice in the northwestern portion of James Bay, but the survey lines ended at the ice edge. Surveys in 1993 and 2001 were flown about 10 days later, and no heavy ice conditions were encountered in either of these later surveys. At the same time, belugas were abundant in the northwestern portion of the bay during the 1993 and 2001 surveys. Fewer animals may have been present in James Bay during the 1985 surveys, or that study may have underestimated whale abundance because the ice-covered region was not surveyed (Smith and Hammill, 1986; Kingsley, 2000).

In 2001, the estimated number of belugas in James Bay ( $N=7900$, not corrected for diving) was more than double the estimated number of animals present in $1993(N=$ 3100 ) and was much greater than would be expected for a population growing at $5 \%$ or less per annum. The marked increase in abundance suggests that there has been an influx of animals into this area, either from EHB or from the Ontario coast of Hudson Bay, where belugas have been seen in the past (Richard et al., 1990). However, we do not 
believe that this influx results from the movement of animals from EHB into James Bay, for two reasons. First, the decrease in the size of the EHB population that has occurred since 1985 is not large enough to account for the increase in the James Bay population, when hunting is taken into account. Second, aerial survey and satellite telemetry data from EHB do not support the hypothesis of a continuous distribution of belugas between Kuujjuaraapik and the entrance to James Bay during late July and August (Smith and Hammill, 1986; Kingsley, 2000; M.O. Hammill, D.W. Doidge and V. Lesage, unpubl. data).

Large numbers of belugas $(N=1300$, not corrected for diving) were observed near James Bay during surveys along the Ontario coast of Hudson Bay in July 1987 (Richard et al., 1990), but few were seen in this area in August 2001 (P. Richard, Fisheries and Oceans Canada, Winnipeg, pers. comm. 2001). We suggest that the large increase in the James Bay estimate may be due in part to movement of animals from the Ontario coast into James Bay, particularly into its northwest sector, during the summer of 2001. However, a much better understanding of the migration patterns and the stock relationships of James Bay belugas is needed to clarify this issue.

Belugas are seen and small numbers continue to be harvested in Ungava Bay during the summer (Lesage et al., 2001). Over the years, aerial surveys have been flown there in July and in August, but no survey has yet detected any animals on transect, and very few sightings have been made overall, indicating that numbers are extremely low (Smith and Hammill, 1986; Kingsley, 2000). At one time, belugas were hunted commercially in Ungava Bay (Reeves and Mitchell, 1987a), and substantial numbers were seen in the estuary of the Mucalic River as recently as the 1960s ( $N=400$, pers. comm. by G. Koneak to T.G. Smith in 1983 [Smith, 1998]), but few animals are seen there today. The continued sightings, combined with knowledge that belugas were once abundant in this area, have led to scepticism among local residents concerning the validity of the survey results. It is possible to estimate a minimum population size needed to detect belugas on transect (Smith and Hammill, 1986). Assuming a clumping factor of 10, and the current proportion of the area covered by the survey (25.5\%), then a population at the surface of 157 animals is needed before an estimate with a $\mathrm{CV}$ of $50 \%$ could be obtained. Kingsley (2000) used off-transect observations to estimate a possible population of 50 animals (upper $95 \%$ confidence limit of 157) in Ungava Bay. Correcting for animals below the surface, we estimate that 400 animals would have to be present in Ungava Bay before an aerial survey using the current design would have a strong probability of detecting animals. An increase in survey coverage would lower this threshold, but this would not change the facts: this population of belugas is extremely small, and hunting must be reduced if it is ever to recover.

The EHB beluga population has declined since 1985. Although the aerial survey data indicate little change between the 1993 and 2001 surveys, the 2001 estimate is extremely sensitive to the detection of a group of 52 animals along one of the survey lines. This group, which represents $33 \%$ of the total number of animals sighted, not only increases the estimates of total abundance, but also has an important impact on the survey variance. Although there is no reason to exclude this observation, it points to the difficulties in trying to evaluate small populations of highly aggregated animals.

Several other indices also provide evidence of a decline in the EHB beluga population. These include a decline over time in the number of animals found in inshore areas (coastal counts), fewer whales counted on transect survey lines in $1993(N=150$ whales $)$ and $2001(N=160)$ than were counted during the 1985 survey ( $N=200$ whales), and a more restricted distribution of offshore sightings (Fig. 3). Shore-based observations conducted in 1983 and 1984 (Caron and Smith, 1990) reported maximum counts of 200+ belugas in the Nastapoka during July and August. These counts are much higher than sightings of 40-60 belugas in 1993 (Doidge, 1994) and 25 animals at a time in August 1998 (Doidge and Lesage, 2001) and in July 2000 and 2001 (D.W. Doidge and M.O. Hammill, unpubl. data). Finally, there has also been a substantial decline in the median age of animals harvested in EHB (data not specific to estuaries), from 13 years during 1980 and 1983-87 to 9.0 years during 1993-2001, as well as a sharp reduction in the proportion of worn teeth (older animals) in the catch (Fig. 5) (Lesage et al., 2001). When considered together, these indices provide strong evidence that the eastern Hudson Bay beluga population has declined since 1985.

In this study, reported harvest data were incorporated into a simple population model and fitted to aerial survey estimates by optimizing both the initial population size and a harvest correction factor. Abundance estimates from the DISTANCE analysis were used as inputs into the model. These estimates were higher than the estimates from the Richards analysis, but are likely still conservative, since no correction was made for detection bias. Furthermore, the model indicates that harvests must be substantially reduced from current levels if the population is to recover.

The model tracked the population decline since 1985 , but the standard errors around the population trajectory are quite wide, indicating considerable uncertainty associated with the actual current population size. Some of this uncertainty is due to the very short time series of only three surveys to which the model was fitted. Additional uncertainty would be expected because of normal interannual variability in environmental conditions, reproductive rates, mortality, and harvesting. We tried to account for some of this uncertainty by linking model parameters to defined statistical distributions and resampling from these distributions during different model runs, instead of representing them by single values. Results from this approach must be viewed only as approximations for Nunavik belugas, because the true values and distribution of the model parameters $\left(\lambda_{\max }, N_{1854}, \theta\right.$, and $\left.b\right)$ are not known. Model 
simulations showed that changes in the struck-and-lost parameter had the greatest impact on model predictions, and this result points to one area where research could be addressed. Changes in $\theta$, the shaping parameter of the density-dependent response, had little impact on model output because the current population of around 2600 belugas is quite small compared to estimated pristine levels of 7875 animals (Reeves and Mitchell, 1987b). The fact that COSEWIC has classified EHB belugas as threatened underlines the need for some conservation concern. At the same time, belugas are still being hunted in Nunavik for subsistence. Within this context is a need for scientific advice on recommended harvest levels. At current reported harvest rates $\left(\mathrm{Mean}_{1997-2001}=119, \mathrm{SD}=12\right)$, there is a $50 \%$ chance that the EHB beluga population could disappear by 2015 . Our results indicate that a harvest of 44 animals (replacement yield) should lead to no change in the population, while a harvest of 28 animals would allow the population to increase at a rate of about $1 \%$ per annum. However, there is considerable uncertainty associated with these estimates.

The depletion of EHB and Ungava Bay beluga stocks and their failure to recover appear to result from a combination of excessive commercial exploitation and high subsistence harvests. Local knowledge attributes the decline to a change in distribution of animals owing to increased vessel traffic (Johannes et al., 2000), but this conclusion is not supported by the available information. In areas such as Little Whale River, the Churchill River estuary (Manitoba), and the Mackenzie River estuary (Northwest Territories), locally abundant concentrations of belugas are still seen in spite of ship traffic, oil and gas exploration activities, commercial whale watching, and subsistence hunting (Norton and Harwood, 1986; M.O. Hammill, pers. observation).

Hunting is inextricably part of the long relationship between aboriginal people and their environment (Gunn, 2001). The subsistence harvesting of belugas is still an important component of the Inuit culture in northern Quebec. At the same time, as modern technologies have been adopted to pursue traditional activities, there has been a failure to understand or recognize the accompanying largerscale impacts of increased hunting capacity on a shared community resource. As a result, the decline in beluga stocks in Nunavik and elsewhere (e.g., Greenland; HeideJorgensen and Reeves, 1996) is remarkably similar to what has been observed under situations of unregulated competition in open-access fisheries throughout the world, where considerations of future benefits are discounted in favour of present harvests (Lande et al., 2001).

In Nunavik, the management of belugas is the responsibility of the federal department, Fisheries and Oceans Canada. Experience elsewhere has shown that centrally imposed management regimes, which do not recognize local interests, increase resistance to acceptance of management objectives and ultimately lead to the failure of such centralized plans (Hutton and Dickson, 2001; Sejersen,
2001). Although considerable consultation between resource managers and users in Nunavik does occur, a formal co-management regime like those in other Canadian jurisdictions (Richard and Pike, 1993; Usher, 1995; FJMC, 1998) has yet to be developed. One challenge to any new management approach will be to coordinate 14 communities with very different perceptions concerning beluga abundance and balance their needs against the need to favour recovery of the EHB beluga population.

The modern rifle, motor-powered vessels, and longliners have eased the task of the hunter, but they have also contributed to a marked expansion of harvesting territory and harvesting capacity. Local resource users need to look beyond the detailed local knowledge they have gained from hunting in their own areas and to consider the larger-scale harvesting impacts of a rapidly expanding population of hunters. Given the overall decline in beluga numbers and continued high levels of harvesting, the possibility of both the EHB and the Ungava Bay belugas stocks' disappearing could become a reality within the next two decades.

\section{ACKNOWLEDGEMENTS}

Amélie Robillard helped with the planning and preparation of the survey. Shaomik Inukpuk participated in the coastal survey of eastern Hudson Bay. Joanassie Ningiuk helped with the logistics and organization of fieldwork. We thank D.W. Doidge for the age and sex structure of the harvests, D. Baillargeon for harvest statistics, and A. Robillard for preparing the map figure.

\section{REFERENCES}

ANONYMOUS. 1999. Nunavik at a glance. Kuujjuaq, Quebec: Makivik Corporation, Economic Development Department.

BARLOW, J., and BOVENG, P. 1991. Modeling age specific mortality for marine mammal populations. Marine Mammal Science 7:50-65.

BRENNIN, R., MURRAY, B.W., FRIESEN, M.K., MAIERS, L.D., CLAYTON, J.W., and WHITE. B.N. 1997. Population genetic structure of beluga whales (Delphinapterus leucas): Mitochondrial DNA sequence variation within and among North American populations. Canadian Journal of Zoology 75:795-802.

BRETON-PROVENCHER, M. 1980. Survey of the beluga population in the Poste de la Baleine region (New Quebec). Report of the International Whaling Commission, Doc SC/32/ SM16. (Translated from French by the Fisheries and Oceans Canada).

BROWN GLADDEN, J.G., FERGUSON, M.M., and CLAYTON, J.W. 1997. Matriarchal genetic population structure of North American beluga whales Delphinapterus leucas (Cetacea: Monodontidae). Molecular Ecology 6:1033-1046.

BROWN GLADDEN, J.G., FERGUSON, M.M., FRIESEN, M.K., and CLAYTON, J.W. 1999. Population structure of North American beluga whales (Delphinapterus leucas) based on nuclear DNA microsatellite variation and contrasted with the 
population structure revealed by mtDNA variation. Molecular Ecology 8:347-363.

BUCKLAND, S.T., ANDERSON, D.R., BURNHAM. K.P., and LAAKE. J.L. 1993. Distance sampling: Estimating abundance of biological populations. London: Chapman \& Hall. 446 p.

BURNS, J.J., and SEAMAN, G.A. 1985. Biology and ecology. Pt II of investigations of belukha whales in coastal waters of western and northern Alaska. Final Report to OCSEAP, Contract NA 81 RAC 00049. Fairbanks: Alaska Department of Fish and Game. 129 p.

CARON, L.M., and SMITH, T.G. 1990. Philopatry and site tenacity of belugas, (Delphinapterus leucas) hunted by the Inuit at the Nastapoka Estuary, eastern Hudson Bay. Canadian Bulletin of Fisheries and Aquatic Sciences 224:69-79.

COCHRAN, W.G. 1977. Sampling techniques. 3rd ed. Toronto: John Wiley \& Sons.

DE MARCH, B.G.E., and MAIERS, L.D. 2001. Stock discrimination of belugas (Delphinapterus leucas) hunted in eastern Hudson Bay, northern Québec, Hudson Strait, and Sanikiluaq (Belcher Islands), using mitochondrial DNA and 15 nuclear microsatellite loci. Canadian Science Advisory Secretariat, Research Document 2001/050. 9 p. URL: http:// www.dfo-mpo.gc.ca/csas/

DEMARCH, B.G.E., and POSTMA, L.D. 2003. Molecular genetic stock discrimination of belugas (Delphinapterus leucas) hunted in eastern Hudson Bay, northern Quebec, Hudson Strait, and Sanikiluaq (Belcher Islands), Canada, and comparisons to adjacent populations. Arctic 56(2):111-124.

DeMASTER, D.P., LOWRY, L.F., FROST, K.J., and BENGTSON, R.A. 2001. The effect of sea state on estimates of abundance for beluga whales (Delphinapterus leucas) in Norton Sound, Alaska. Fisheries Bulletin 99:197-201.

DOAN, K.H., and DOUGLAS, C.W. 1953. Beluga of the Churchill region of Hudson Bay. Fisheries Research Board of Canada Bulletin 98. 27 p.

DOIDGE, D.W. 1990. Age and stage based analysis of the population dynamics of beluga whales, Delphinapterus leucas, with particular reference to the northern Quebec population. Ph.D. thesis, McGill University, Montreal. 190 p.

1994. Landbased observations of beluga whales at the Little Whale and Nastapoka Rivers, eastern Hudson Bay, summer 1993. Funded by Fisheries and Oceans Aboriginal Fisheries Strategy. Available from the Maurice Lamontagne Institute, Box 1000, Mont-Joli, Quebec G5H 3Z4, Canada. 30 p.

DOIDGE, D.W., and LESAGE, V. 2001. Use of the Nastapoka and Little Whale River estuaries by humans and beluga during summer 2001. Report prepared by Makivik Corporation for Environment Canada. Available from the Maurice Lamontagne Institute, Box 1000, Mont-Joli, Quebec G5H 3Z4, Canada. 34 p.

EFRON, B. 1982. The jack-knife, the bootstrap, and other resampling plans. Philadelphia: Society for Industrial and Applied Mathematics. 92 p.

FINLEY, K.J., MILLER, G.W., ALLARD, M., DAVIS, R.A., and EVANS, C.R. 1982. The belugas (Delphinapterus leucas) of northern Quebec: Distribution, abundance, stock identity, catch history and management. Canadian Technical Report of Fisheries and Aquatic Sciences 1123. v + 57 p.
FJMC (FISHERIES JOINT MANAGEMENT COMMITTEE). 1998. Beaufort Sea beluga management plan. 3rd ed. Available from the Joint Secretariat, Box 2120, Inuvik, Northwest Territories X0E 0T0, Canada.

GOSSELIN, J.-F., LESAGE, V., HAMMILL, M.O., and BOURDAGES, H. 2002. Abundance indices of beluga in James Bay, eastern Hudson Bay and Ungava Bay in summer 2001. Canadian Science Advisory Secretariat Research Document 2002/042.27 p. Available from the Maurice Lamontagne Institute, Box 1000, Mont-Joli, Quebec G5H 3Z4, Canada. URL: http:// www.dfo-mpo.gc.ca/csas

GUNN, A. 2001. Conservation and resource use in Arctic ecosystems. In: Reynolds, J.D., Mace, G.M., Redford, K.H., and Robinson, J.G., eds. Conservation of exploited species. Cambridge: Cambridge University Press. 424-439.

HARWOOD, L.A., INNES, S., NORTON, P., and KINGSLEY, M.C.S. 1996. Distribution and abundance of beluga whales in the Mackenzie estuary, southeast Beaufort Sea, and west Amundsen Gulf during late July 1992. Canadian Journal of Fisheries and Aquatic Sciences 53:2262-2273.

HEIDE-JØRGENSEN, M.P., and REEVES, R.R. 1996. Evidence of a decline in beluga, Delphinapterus leucas, abundance off West Greenland. ICES Journal of Marine Science 53:61 -72.

HOBBS, R.C., RUGH, D.J., and DeMASTER, D.P. 2000. Abundance of belugas, Delphinapterus leucas, in Cook Inlet, Alaska, 1994-2000. Marine Fisheries Review 62:37-45.

HUTTON, J., and DICKSON, B. 2001. Conservation out of exploitation: A silk purse from a sow's ear. In: Reynolds, J.D., Mace, G.M., Redford, K.H., and Robinson, J.G., eds. Conservation of exploited species. Cambridge: Cambridge University Press. 440-461.

INNES, S., and STEWART, R.E.A. 2002. Population size and yield of Baffin Bay beluga(Delphinapterus leucas) stocks. NAMMCO Scientific Publications 4:225-238.

JOHANNES, R.E., FREEMAN, M.M.R., and HAMILTON, R.J. 2000. Ignore fishers' knowledge and miss the boat. Fish and Fisheries 1:257-271.

JONKEL, C.J. 1969. White whales wintering in James Bay. Journal of the Fisheries Research Board of Canada 26:2205-2207.

KAYSUYA, T., SERGEANT, D.E., and TANAKA, K. 1988. Reexamination of life history parameters of long-finned pilot whales in Newfoundland waters. Scientific Reports of the Whales Research Institute 39:103-119.

KINGSLEY, M.C.S. 1989. Population dynamics of the narwhal (Monodon monoceros): An initial assessment (Odontoceti: Monodontidae). The Journal of Zoology of the Zoological Society of London 219:201-208.

- 2000. Numbers and distribution of belugas in Hudson Bay, James Bay and Ungava Bay in Canada during the summer of 1993. Fisheries Bulletin 98:736-747.

KINGSLEY, M.C.S., and GAUTHIER, I. 2002. Visibility of St Lawrence belugas to aerial photography, estimated by direct observation. NAMMCO Scientific Publications 4:259-270.

KINGSLEY, M.C.S., and REEVES, R.R. 1998. Aerial surveys of cetaceans in the Gulf of St Lawrence in 1995 and 1996. Canadian Journal of Zoology 76:1529-1550. 
KINGSLEY, M.C.S., STIRLING, I., and CALVERT, W.A. 1985. The distribution and abundance of seals in the Canadian high Arctic, 1980-82. Canadian Journal of Fisheries and Aquatic Sciences 42:1189-1210.

KINGSLEY, M.C.S., RICHARD, P., and INNES, S. 1995. The effect of management options on the dynamics of beluga populations. Unpubl. report prepared for the Northern Quebec and Native Affairs Division, Fisheries and Oceans Canada, Quebec Region. Available from the Maurice Lamontagne Institute, Box 1000, Mont-Joli, Quebec G5H 3Z4, Canada. 21 p.

KINGSLEY, M.C.S., GOSSELIN, S., and SLENO, G.A. 2001. Movements and dive behavior of belugas in northern Quebec. Arctic 54(3):262-275.

LANDE, R., SÆTHER, B.-E., and ENGEN, S. 2001. Sustainable exploitation of fluctuating populations. In: Reynolds, J.D., Mace, G.M., Redford, K.H., and Robinson, J.G, eds. Conservation of exploited species. Cambridge: Cambridge University Press. 67-86.

LESAGE, V., DOIDGE, D.W., and FIBICH, R. 2001. Harvest statistics for beluga whales in Nunavik: 1974-2000. Canadian Science Advisory Secretariat, Research Document 2001/022. 35 p. Available from the Maurice Lamontagne Institute, Box 1000, Mont-Joli, Quebec G5H 3Z4, Canada. URL: http:// www.dfo-mpo.gc.ca/csas/

NORTON,P., and HARWOOD. L.A. 1986. Distribution, abundance and behaviour of white whales in the Mackenzie Estuary. Environmental Studies Research Funds Report 036. 73 p.

PELLA, J.J., and THOMLINSON, P.K. 1969. A generalized stock production model. Bulletin of the Inter-American Tropical Tuna Commission 13:420-496.

REEVES, R.R., and MITCHELL, E.D. 1987a. Catch history, former abundance and distribution of white whales in Hudson Strait and Ungava Bay. Naturaliste Canadien 114:1-65. . 1987b. History of white whale (Delphinapterus leucas) exploitation in eastern Hudson Bay and James Bay. Canadian Special Publications on Fisheries and Aquatic Sciences 95. 45 p.
1989. Status of white whales, Delphinapterus leucas, in Ungava Bay and eastern Hudson Bay. Canadian Field-Naturalist 103:220-239.

REILLY, S.B., and BARLOW, J. 1986. Rates of increase in dolphin population size. Fisheries Bulletin 84:527-533.

RICHARD, P., and PIKE, D.G. 1993. Small whale co-management in the eastern Canadian Arctic: A case history and analysis. Arctic 46(2):138-143.

RICHARD, P.R., ORR, J.R., and BARBER, D.G. 1990. The distribution and abundance of belugas, Delphinapterus leucas, in eastern Canadian waters: A review and update. In: Smith, T.G., St. Aubin, D.J., and Geraci, J.R., eds. Advances in research on the beluga whale Delphinapterus leucas. Canadian Bulletin of Fisheries and Aquatic Sciences 224. 23-38.

RICHARDS, F.J. 1959. A flexible growth function for empirical use. Journal of Experimental Botany 10:290-300.

SEJERSEN, F. 2001. Hunting and management of beluga whales (Delphinapterus leucas) in Greenland: Changing strategies to cope with new national and local interests. Arctic 54(4): $431-443$.

SERGEANT, D.E. 1973. Biology of white whales (Delphinapterus leucas) in western Hudson Bay. Journal of the Fisheries Research Board of Canada 30:1065-1090.

SMITH, T.G. 1998. Seasonal movements and migrations of belugas, Delphinapterus leucas, along the Nunavik coastlines: Evidence from harvest statistics, game reports, local knowledge and scientific studies. Available from the Maurice Lamontagne Institute, Box 1000, Mont-Joli, Quebec G5H 3Z4, Canada. 31 p.

SMITH, T.G., and HAMMILL, M.O. 1986. Population estimates of white whale, Delphinapterus leucas, in James Bay, Eastern Hudson Bay and Ungava Bay. Canadian Journal of Fisheries and Aquatic Sciences 43:1982-1987.

USHER, P.J. 1995. Comanagement of natural resources: Some aspects of the Canadian experience. In: Peterson, D.L., and Johnson, D.R., eds. Human ecology and climate: People and resources in the Far North. Washington: Taylor \& Francis. $197-206$ 